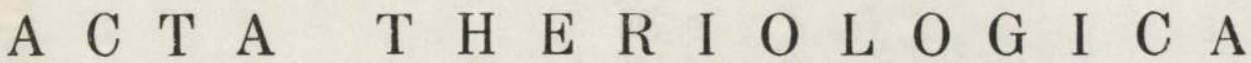 \\ VOL. XIV, 13: 167-179. \\ BIAŁOWIEŻA \\ 30.VIII.1969
}

Paweł M I G U L A

\section{Bioenergetics of Pregnancy and Lactation in European Common Vole*}

[With 1 Table and 2 Figs.]

\begin{abstract}
The food consumption and assimilation were determined in the females of the European common vole, Microtus arvalis (P a 11 a s, 1779). The measurements were carried out using 17 pregnant and lactating females as well as 20 non-reproducing females. During the pregnancy the energy requirement of a female with average body weight $28.5 \mathrm{~g}$ amounts to the mean value of $13.9 \mathrm{kcal} / \mathrm{day}$ and is higher by $32 \%$ as compared with the control females. The daily food assimilation of the female ( $25.2 \mathrm{~g}$ body weight) during the lactation is equal to $26.6 \mathrm{kcal} /$ day and exceeds by $133 \%$ the corresponding figure for the non-reproducing female. During the whole period of pregnancy and lactation the female assimilates additionally $304 \mathrm{kcal}$ (including 60.5 kcal for gestation and $243.5 \mathrm{kcal}$ for lactation). Hence the metabolism increases in this period by $82.5 \%$ on the average. To produce and nurse one young vole the mother requires $75.9 \mathrm{kcal}$. The losses of energy with feces are equal to $8.95 \%$ and with urine to $3.33 \%$, thus the energy present in the food is utilised in the very high degree $(87.72 \%)$. The efficiency of net production in the breeding period is also high and equal to $13.9 \%$ during the pregnancy and $15.4 \%$ during the lactation.
\end{abstract}

\section{INTRODUCTION}

The European common vole, Microtus arvalis ( $\mathrm{Pa} 11 \mathrm{as}, 1779)$ is the most numerous rodent in the field ecosystems of the almost whole Europe. This species is characterized by the great breeding abilities ( $\mathrm{F} \mathrm{ran} \mathrm{k,} \mathrm{1957).} \mathrm{In} \mathrm{the} \mathrm{favourable}$ circumstances the intensive reproduction may last all the year round $(\mathrm{Pe} l \mathrm{ik}$ a $\mathrm{n}$, 1959; B a s henina, 1962). This rodent is the most dangerous pest of the field cultures, especially in periods of mass occurrence ( $\mathrm{Skuratowicz}, 1963$ ). In spite of these facts very little is known of the physiology, and especially of the metabolism of the common vole. The bioenergetics of this animal was studied by measuring the respiration ( $\mathrm{J}$ anský, 1959; B a shenina, 1962; Trojan \& Wojciechowska, 1967a; 1967b; 1968) as well as the digestibility and assimilation of natural foods (Drożd $\dot{z}, 1968 \mathrm{a}$ ). Estimation of the energy flow through

* This study was carried out under the Small Mammal Project of the International Biological Programme in Poland. 
the population of the common vole may help to determine the exact losses in field cultures resulting from the action of these animals. Taking into consideration the bioenergetics of small rodents the breeding period is very expensive and hence it plays a significant role in the energy flow through their populations (D a vis \& Golle y, 1963).

During pregnancy the food requirement of the rodent females increases slightly but during lactation it rises drastically. This has been repeatedly observed both in laboratory mice and rats (Brody, 1945; Nels on \& Evans, 1961; Fell, Smith \& Campbel1, 1963; Barnett \& Little, 1965). Among wild rodents the bioenergetics of pregnancy and lactation was studied by the food ration method in the bank vole, Clethrionomys glareolus (S ch reber, 1780), (K a c z-

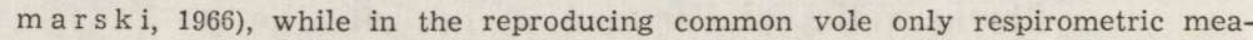
surements were carried out to determine the resting metabolic rate ( $\mathrm{T} \mathrm{roj}$ a $\mathrm{n}$ \& Wojciechowska, 1967a). The purpose of the present study was to estimate the energy requirement of the common vole during the whole period of pregnancy and lactation by using the food ration method.

\section{MATERIALS AND METHODS}

The experiments were carried out mainly on the wild common vole captured in Ojców near Kraków and partly using animals reared in the Mammals Research Institute, Polish Academy of Sciences at Białowieża.

Sex activity of females was estimated by the daily vaginal smears (S n e 11, 1956). The appearance of the plug or the copulation were regarded as the beginning of pregnancy in the common vole (B a shenina, 1962; Asde1l, 1965). Pregnant females were separated from males and placed singly in two-chamber cages $(40 \times 25 \times 15 \mathrm{~cm})$ equipped with nests made of tissue or cotton-wool. In such conditions females were kept during the whole period of pregnancy (18 days on the average) and lactation (16 days). The animals were reared in a room with fairly constant temperature about $20^{\circ} \mathrm{C}$ and 12 hours light daily rhytm.

The diet was diversified and composed of oat, carrot and milk supplied in the calibrated bottle. In 24 hours intervals non-consumed food was removed and replaced by the fresh ration. The food consumption was determined by the weighing with appropriate correction for drying of the food (carrot). At the same time the body weight of the female and the increase in the biomass of the litter were measured. The full period of pregnancy and lactation was studied in the described manner in 17 females of the common vole.

Some additional experiments on the digestibility and assimilation of food were carried out in metabolic cages, by the balance-sheet method (D ro żd $\dot{z}, 1968$ b). For this purpose 15 non-reproducing females and 5 pregnant females of the common vole, treated as the control, were used. Such experiments lasted for 10 days and consisted of two 5-day periods. In the initial period animals were left in normal breeding cages but supplied with the tested diet. During the proper 5 -day period animals were kept in metabolic cages enabling a separate collection of feces and urine. The definite amount of food in slight excess was given every day. Urine was acidified with $1 \% \mathrm{H}_{2} \mathrm{SO}_{4}$ and kept as well as feces in closed containers in the refrigerator until the moment of analysis. In the material preserved in such conditions no change in the caloric value or nitrogen content occurs (Fuller \& $\mathrm{Cadenhaed,1965).} \mathrm{The} \mathrm{females} \mathrm{were} \mathrm{weighed} \mathrm{at} \mathrm{the}$ beginning and at the end of experimental period in metabolic cages. 
The caloric value of dried samples of oat, carrot, milk and feces was determined in the calorimetric bomb of the Berthelot system (G ó recki, 1965a). Urine was evaporated in a vacuum oven on the polythene foil and subsequently combusted in the calorimetric bomb ( $\mathrm{Nijkamp}, 1965)$.

In the studied animals daily food consumption was determined and knowing the level of assimilation in control females (non-reproducing or pregnant) the energy requirement could be calculated. In the control females the food consumption, losses of energy with feces and urine as well as daily energy requirement were measured.

\section{RESULTS}

\section{Energy Requirement in Control Females}

A non-reproducing female of the mean body weight $25.3 \pm 2.3 \mathrm{~g}$ consumed daily, on the average, $2.65 \mathrm{~g}$ of oat, $8.11 \mathrm{~g}$ of carrot, and $6.2 \mathrm{ml}$ of milk. The caloric values of food as well as feces and urine determined in the calorimetric bomb are compared in Table 1 . The non-reproducing female consumed daily food corresponding to the

Table 1.

Caloric values of the diet, faeces and urine determined in the calorimetric bomb.

\begin{tabular}{|l|c|c|c|}
\hline Material & $\begin{array}{c}\text { Number of } \\
\text { samples }\end{array}$ & $\begin{array}{c}\text { Kcal/g of dry } \\
\text { weight }\end{array}$ & $\begin{array}{c}\text { Kcal/g of fresh } \\
\text { weight }\end{array}$ \\
\hline Oats & 4 & 4.342 & 3.828 \\
Carrots & 4 & 4.079 & 0.454 \\
Milk & 4 & 5.076 & 0.507 \\
Faeces & 6 & 4.418 & - \\
Urine & 3 & - & 0.079 \\
\hline
\end{tabular}

energy value of $16.98 \mathrm{kcal}$. At the same time the caloric loss in feces was $1.52 \pm 0.41 \mathrm{kcal}(8.95 \%$ of energy ingested) and in urine $0.56 \pm 0.20$ kcal $(3.33 \%$ of energy ingested). Hence the metabolizable energy (assimilation) amounted in these animals to $14.9 \mathrm{kcal} /$ day or $87.72 \% \pm$ $3.51 \%$ of the energy present in the consumed food.

The pregnant females also utilized in high degree the consumed food and the metabolizable energy was equal to $86.6 \% \pm 3.81 \%$. Since no statistically significant changes in the level of assimilation were found between the pregnant and non-reproducing females the value of $87.7 \%$ for the metabolizable energy was assumed for all the reproducing females. The results of all described experiment are expressed in the assimilated or metabolizable energy.

To calculate the daily cost of maintenance further corrections for changes in the body weight of animals were also applied. For this reason 
$9 \mathrm{kcal}$ was subtracted for every one gram of increase of the female biomass during the experiment, while $7 \mathrm{kcal}$ was added for loss of the body weight by 1 gram (D rożd ż, 1968a). The mean body weight of control females during 5 day period rose by $0.32 \mathrm{~g}$ on the average, thus the correction was small and amounted to $0.57 \mathrm{kcal} /$ animal/day. The daily energy requirement determined in metabolic cages was further reduced by $20 \%$ taking into account additional losses of energy resulting from lack of the nest ( $\mathrm{D} \mathrm{r}$ o ż d ż, 1968a). Finally the cost of maintenance for the non-reproducing female was established as 0.453 $\mathrm{kcal} / \mathrm{g} /$ day. This value may constitute the basis of evaluation of the energetic expenses beared by the reproducing females during gestation and lactation. The mean body weight of the female in the first day of pregnancy was equal to $23.2 \mathrm{~g}$ while that of lactating female $25.2 \mathrm{~g}$. The energy requirement of non-reproducing females of corresponding body weights should amount to 10.5 and $11.4 \mathrm{kcal}$ of metabolizable energy per day.

\section{Period of Pregnancy}

The quantity of energy assimilated by females of the common vole during gestation and lactation is depicted in Fig. 1. This graph represents the mean values of 17 animals. The solid line corresponds to the level of assimilation while broken lines show the comparable energy requirement in the non-reproducing females.

During the pregnancy, lasting 18 days on the average, the female increased the mean body weight from $23.2 \pm 2.1 \mathrm{~g}$ to $33.9 \pm 3.0 \mathrm{~g}$. Such fast increase of the biomass was possible due to enhanced food consumption. The fairly sharp rise in the amount of assimilated food was observed already in the first week of pregnancy. The appropriate figure for the 6 th day is equal to $13.39 \pm 1.3 \mathrm{kcal}$ per animal. Between the 7 th and 10th day the assimilation is maintained on the approximate level $13.6 \mathrm{kcal} / \mathrm{animal} / \mathrm{day}$. In the period 11 to 17 days further gradual increase in the requirement of food was observed. The maximum usually occurred at the 17 th day when the female assimilated $15.98 \pm 2.4 \mathrm{kcal}$ on the average. On the 18 th day, being the day of parturition, the mean food consumption was usually depressed (daily assimilation amounted to $13.48 \pm 2.6 \mathrm{kcal}$ per animal).

During 18 days of gestation the female assimilated $249.7 \pm 15.9 \mathrm{kcal}$ on the average. At the same time the energy requirement of the control female should not exceed $189.0 \mathrm{kcal}$. Hence the additional energy assimilated during the pregnancy amounts to $60.5 \mathrm{kcal}$ exceeding the requirement of the control female by $32 \%$. This energy is utilised for 
production of a litter consisting on the average of 4.25 animals of the total weight $7.42 \mathrm{~g}$ at birth.

\section{Peried of Lactation}

This period is characterized by much higher increase of the energy consumption than during pregnancy. Within first 6 days the quantity of consumed metabolizable energy is almost doubled and reaches $23.5 \pm$ $3.91 \mathrm{kcal}$ per animal. Some slowing down of this increase in the energy requirement takes place in the subsequent days (6-9) when the corresponding figure remains within limits $24 \mathrm{kcal} /$ day. Between the 10 th and 15th day further sharp rise of the food utilisation by the female occurs (Fig. 1). The amount of assimilated food reaches the

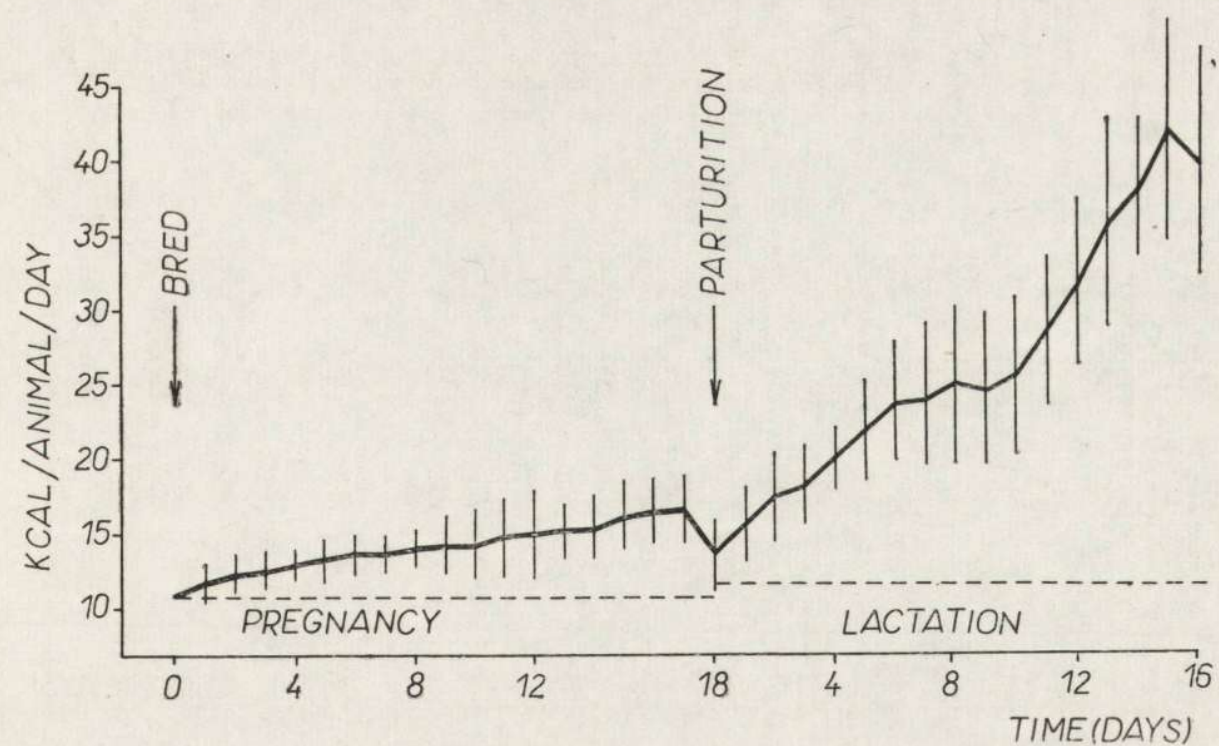

Fig. 1. Energy requirement (assimilation) of the common vole females during pregnancy and lactation. The curve represents mean values for 17 females standard deviations for each day are marked as vertical lines. Broken lines correspond to the energy requirement in the same number of non-reproducing females.

maximum at 15 day and is equal then to $41.99 \pm 7.71 \mathrm{kcal}$ per animal. At this moment, however, the baby-voles are able of weaning. First of all they drink milk from the bottle and during next 2 or 3 days they eat also some solid food (carrot and oat). Hence the energy requirement of the female at the 14 th day $(37.97 \pm 4.7 \mathrm{kcal}$ per animal) should be regarded as the maximal effort. The values for subsequent days may be overestimated since baby-voles eat part of the food supplied for their mother. 
The increase in the energy ingested by the female is well correlated with the rate of growth of the litter biomass (Fig. 2). During first six days of life the baby-vole gains on the average $0.31 \mathrm{~g} /$ day, and during subsequent four days $0.42 \mathrm{~g} /$ day. The most rapid growth $(0.75 \mathrm{~g} /$ day $)$ occurs in the last six days of lactation. As a result the body weight of the average weaning common vole in the 16 th day amounts to $9.87 \mathrm{~g}$.

During 16 days of lactation the female assimilates on the whole $426.1 \mathrm{kcal}$. The energy requirement of the control female of identical body weight may amount in this period to $182.9 \mathrm{kcal}$ only. Hence the lactating female assimilates additional $243.2 \mathrm{kcal}$, i.e. $133 \%$ more than the control female. This energy enables feeding the litter consisting of

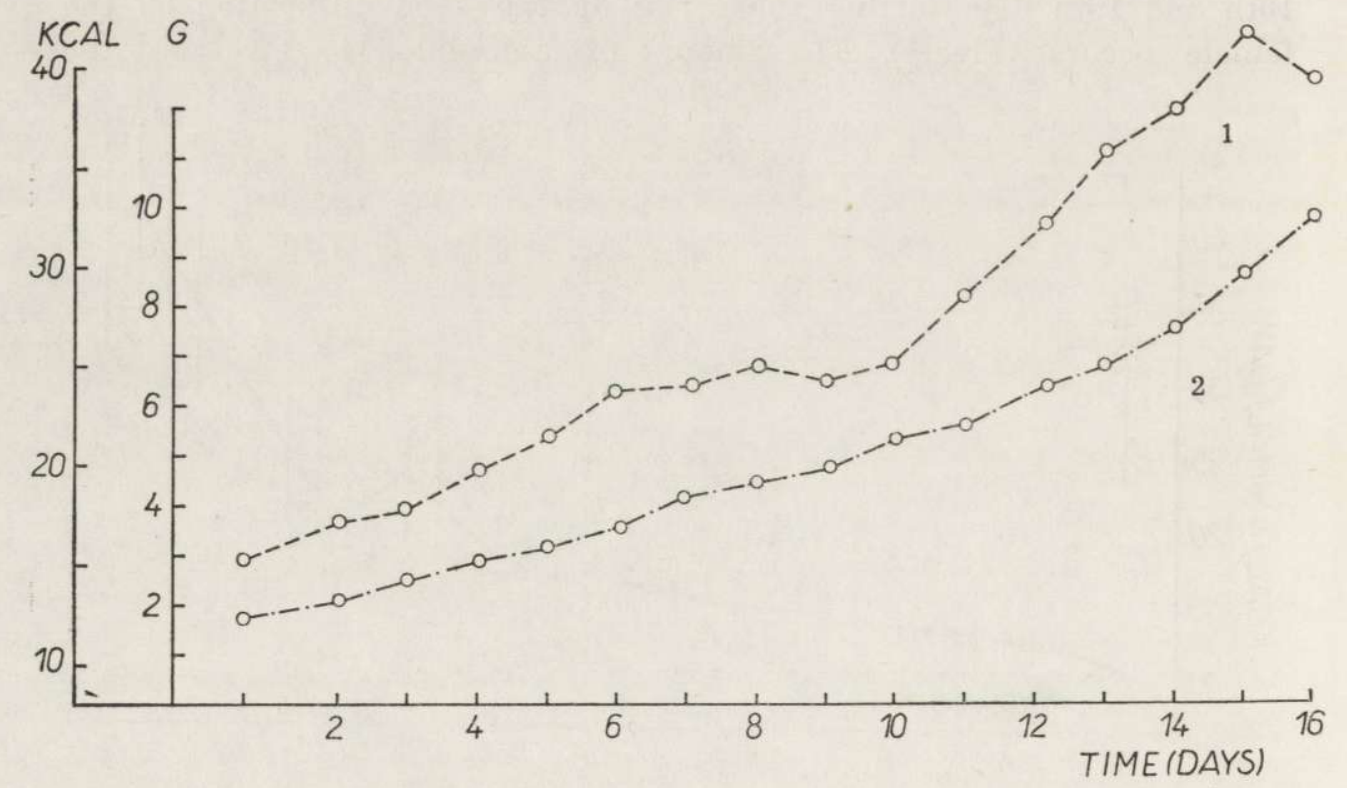

Fig. 2. Daily energy requirement of the female during lactation (1) and mean growth of the young vole in grams (2). Curves represent the mean values for 17 females with litters.

4 animals. The mortality of the new-born voles was very low and in 17 litters with the average number 4.25 animals 4 voles survived till weaning.

There are interesting individual differences in the bioenergetics of females related to the litter size. Among 17 lactating females the majority $(\mathrm{N}=14)$ had 4 or 5 baby-voles while only 3 females had small litters consisting of 1 to 3 animals. During lactation the females feeding more numerous litter assimilated additional $256 \mathrm{kcal}$ while the corresponding figure for others was approximately $30 \%$ lower and varied 
between 147 and $233 \mathrm{kcal}$. In spite of this fact the expenditure of energy for feeding one young vole from the more numerous litter is only 64.1 kcal, while in the small litter it amounts to $77.7 \mathrm{kcal}$. Larger quantity of energy required for feeding young voles in smaller litters enabled much faster growth. The broad range of individual variability presented in Fig. 1 may be explained, apart from other factors, by the various size of litters.

On the whole during 34 days of pregnancy and lactation the female ingests on the average $770 \mathrm{kcal}$ of the energy present in the consumed food, from which $676 \mathrm{kcal}$ are assimilated. One can estimate that from this amount $372 \mathrm{kcal}$ are used for the maintenance of the female alone while $304 \mathrm{kcal}$ correspond to the cost of production and feeding the young voles. Hence for every one young vole the female has to assimilate additional $75.9 \mathrm{kcal}$. The energy requirements of the female during the whole period of gestation and lactation are increased on the average by $82.5 \%$.

\section{Efficiency of Pregnancy and Lactation}

The efficiency of net production during the breeding period is determined by the ratio of energetic value of the produced and raised to weaning young animals, to the energetic value of the food assimilated additionally by the female in this period.

The pregnancy lasting 18 days resulted in a litter of the average biomass $7.42 \mathrm{~g}$. Assuming the caloric value of the newborn as equal to $0.94 \mathrm{kcal} / \mathrm{g}$ body weight (G ó r e c k i, 1965b) the mean litter corresponds to $6.98 \mathrm{kcal}$. The energy contained in the placenta and fetal membranes can be estimated by the comparison with laboratory mice ( $\mathrm{Mus}$ ia$1 \mathrm{e} \mathrm{k}, 1968$ ) and is approximately equal to $1.5 \mathrm{kcal} / \mathrm{litter}$ (G ó re ck i, $1965 \mathrm{~b})$. Thus the total production of biomass during the pregnancy amounted to $8.48 \mathrm{kcal}$ and the female assimilated additionally $60.5 \mathrm{kcal}$. One can conclude that the total efficiency of production during the pregnancy is $13.9 \%$ or $11.5 \%$ considering the biomass of baby-voles alone.

The efficiency for the period of lactation may be calculated in a similar manner. Total biomass of the average litter after 16 days of nursing increased by $31.2 \mathrm{~g}$. Since the caloric value of the voles leaving the nest is not known, the figure $1.2 \mathrm{kcal} / \mathrm{g}$, as the intermediate value between the new-born and adult voles, has been used in the calculations. Hence the energetic value of the weaning litter amounted to $37.56 \mathrm{kcal}$ while the female used additionally $243.2 \mathrm{kcal}$. The efficiency of this period was therefore even higher than the pregnancy and equal to $15.4 \%$. 


\section{DISCUSSION}

The food ration method used in the present experiments depends on the determination of the daily food ingestion $(C)$ by the animal and estimation of the metabolizable energy $(A)$ after subtracting the caloric value of feces $(F)$ and urine $(U)$. This is illustrated by the simple equation (P e tr u s e w i c z, 1967):

$$
A=C-(F U)
$$

When the body weight of the animal remains constant, the whole metabolizable energy is used for the cost of maintenance. In the case of negligible changes in the body weight of the female at the beginning of pregnancy and the end of lactation ( 23.2 and $24.4 \mathrm{~g}$ ) one can assume with a minimal error that the total additionally assimilated energy has been utilised for the production and feeding the litter. Thus after $\mathrm{Tr}$ ojan \& Wojciechowska (1967a):

$$
A=P_{\text {juv }}+\left(R_{\uparrow}+R_{\text {juv }}\right)
$$

where: $A$ - assimilation during the reproduction period;

$P_{\text {juv }}$ - biomass of the young at the end of the period of being nursed by the mother (16th day);

$R_{\rho}$ - maintenance expenditure by the female during the reproduction period;

$R_{\text {juv }}$ - maintenance expenditure by the litter to the end of the nursing period.

After subtracting the cost of maintenance of the female alone $(R O$ it is possible to estimate the expenses related to the production and feeding the young voles. The maintenance expenditure of the common vole based on the assimilation of food is very close to the values obtained by the respirometric method ( $A D M R$ - average daily metabolic rate) (Grodziński, 1967; Drożd ż, 1968a). The figure of 0.453 $\mathrm{kcal} / \mathrm{g} /$ day; determined in the present study for non-reproducing females, corresponds very well to the results of the above-mentioned authors.

The coefficient of digestibility of the supplied diet (oat, carrot and milk) was lower by only $1.3 \%$ comparing with the coefficient for the oat alone determined by D r o ż d ż (1968a) for the common vole. On the other hand this value is higher by $2.5 \%$ comparing with the digestibility coefficient found for similar diet in the bank vole (K a c z marski, 1966). During pregnancy and lactation, in spite of the increased food consumption, the digestibility coefficient is not altered, both in the common and bank voles. The stability of this coefficient during en- 
hanced food consumption is possible owing to the periodical sincrease" of the alimentary tract in the reproducing females of voles and mice (M y r h a, 1964; 1965). Hypertrophic and hyperplastic changes in the intestine walls of such animals during the breeding period were reported (F e 11 et al., 1963).

The period of pregnancy is characterized by the drop in the resting metabolic rate $(R M R)$ computed per unit of the body weight ( $\mathrm{Tr}$ o ja n \& Wojciechowska, 1967a) and perhaps by the decreased activity of the female (D a vis \& Golley, 1963). The rapid growth of the embryos results in the enhancement of the energy uptake by the female (Fig. 1). By the end of gestation the metabolism of the female increases, but after expressing the result per gram of the body weight a drop is observed (Bashenina, 1962; Trojan \& Wojciechowska, 1967a).

The rapid increase of energy requirement during lactation exceeds the corresponding figures for pregnancy by the factor of two. This results from the production of milk as well as from the increased (by approximately $28 \%$ ) the daily cost of maintenance of the female alone ( Trojan \& Wojciechowska, 1967a). The energy ingested by the female does not increase at a steady rate (Fig. 1). After the initial sharp rise of the assimilation a partial restraining is observed between the 6th and 9th day of lactation. In this period young voles are developing quickly their fur and simultaneously they become able of the metabolic thermoregulation (B a s h e n in a, 1962). The highest rise in the energy requirement of females is observed after the 10th day of lactation. Very often it is accompanied by loss of the body weight since the energy contained in the adipose tissue is being mobilized. At this time young voles start using their eyes and this fact increases their activity and leads to the most intensive growth (Fig. 2). The period of lactation is virtually terminated in the common vole after 16 days but the young may try the independent feeding already around the 15th day, or even earlier. B a shenina (1962) reported the presence not only milk but also some green food in the stomach of 10 days old voles. This fact introduces some uncertainty into our calculations since it is not known what proportion of the food is consumed directly by the young voles. The terminal part of the curve representing the increase of energy requirement of the lactating female is influenced most likely by these factors (Fig. 1).

The very high efficiency of pregnancy and lactation has been observed not only in the common vole but also in the bank vole ( $\mathrm{K} \mathrm{a} \mathrm{c} \mathrm{z-}$ $\mathrm{m}$ arski, 1966). In this last species the efficiency of increase in the weight of litter was also higher during lactation (14.6\%) than during 
pregnancy $(11.8 \%)$. This fact is particularly interesting since during the pregnancy the production of the biomass of young voles occurs at the same "trophic level " (i.e. in the mother's organism), while during lactation the increase in the body weight of the litter depends not only on the production of milk by the mother but also on the assimilation of this food by the baby-voles. Such great efficiency of lactation may be explained by the high caloric value of milk of small rodents (S p e c t o r, 1956). Also the total efficiency during pregnancy and lactation is similar in the common and bank voles $(13.2 \%$ and $14.6 \%)$.

When the results of $\mathrm{Kaczmarski}$ (l.c.) are expressed as the energy assimilated, and not the energy digested, it appears that in the bank vole the cost of production and nursing of one litter consisting of 4 young animals is higher by approximately $20 \%$ than the corresponding in the common vole females.

From the point of view of the bioenergetics especially interesting is the ratio of energy comprised in the produced litter to the caloric value of the body weight of the female. The female of the mean body weight of $25 \mathrm{~g}$ corresponds to $37.5 \mathrm{kcal}$ ( $\mathrm{G}$ ó r e c k i, 1965b). The litter containing on the average 4 young voles represents at weaning the caloric value of $47 \mathrm{kcal}(4$ specimens $\times 9.8 \mathrm{~g} \times 1.2 \mathrm{kcal})$. Hence one litter at the moment of weaning exceeds the caloric value of the mother. During one year the female of the common vole can produce 4 to 5 litters ( $\mathrm{S} \mathrm{k} \mathrm{u}$ $\mathrm{r}$ a t o wi c z, l.c.). In this period the net production due to reproduction $\left(P_{r}\right)$ exceeds by almost seven times the production of growth $\left(P_{g}\right)$. It is probably one of the record results in the world of mammals.

The studies of the bioenergetics of the reproducing common vole carried out by the respirometric method (Trojan \& Wojciechow$\mathrm{ska}, 1967)$ and by the food ration method brought about several surprisingly similar results. The increase of energy requirement of the reproducing females was estimated as $80.5 \%$ from oxygen consumption and $82.5 \%$ from food assimilation. Similarly the costs of producing and nursing one young vole were $78.4 \mathrm{kcal}$ and $75.9 \mathrm{kcal}$ respectively. Some discrepancies in the cost of maintenance result probably from the different size of the studied females and their various fertility.

From the data discussed above one can conclude that the energy requirement of the reproducing female increases by at least $80 \%$. Such great change should be taken into consideration during the construction of daily energy budgets $(D E B)$ of the common vole ( $\mathrm{Grodzinski} \mathrm{\&}$ G ór e cki, 1967) as well as in the balances of energy flow through the population of these rodents. The appropriate corrections can be applied in two ways: (1) calculation for the mean specimen of the population. or (2) addition after estimation of the number of litters in the whole 
population. In both cases the reliability of the correction will depend on the accuracy of estimation of the reproduction itself - the proportion of sexes, number of reproducing females, number and size of litters during the year.

The energy expenses of the reproducing females in natural conditions may be even higher than those determined in the laboratory. In natural populations of the common vole the period of lactation often overlaps the beginning of the next pregnancy, and many females prolong the period of nursing (Chitty, 1957; Frank, 1952).

Acknowledgements: The author wishes to express his sincere thanks to Dr. A. Dro ż $\dot{z}$ for continuous guidance throughout this study and help in writing, as well as to Dr. W. Grodziński and Dr. A. Górecki for critical evaluation of the manuscript.

\section{REFERENCES}

1. A s d e 11 S. A., 1965: Patterns of mammalian reproduction. Cornell Univ. Press: $1-670$, Ithaca, New York.

2. Barnett S. A. \& Little M. J., 1965: Maternal performance in mice at $-3^{\circ} \mathrm{C}$ : food consumption and fertility. Proc. Royal Soc., B, 162: 492-501.

3. B a shenina N. V., 1962: Ekologia obyknovennoj polevki. Izd. Mosk. Univ.: 1-307, Moskva.

4. Brody S., 1945: Bioenergetics and growth. Reinhold Publ. Corp.: 1-1023. New York,

5. Chitty H., 1957: The oestrus cycle and gestation period in the lactating field vole, M. agrestis. J. Endocrinol., 15, 3: 279-283.

6. Davis P. E. \& Golle y F. B., 1963: Principles in mammalogy. Reinhold Publ. Corp.: $1-335$. New York.

7. Drożd ż A., 1968a: Digestibility and assimilation of natural foods in small rodents. Acta theriol., 13, 21: 367-389.

8. Drożdż A., 1968b: Studies on the digestibility and assimilation of foods in rodents. Ekol. pol. B, 14, 2: 147-159. [In Polish with English summ.].

9. Fell B. F., Smith K. A. \& Campbell R. M., 1963: Hypertrofic and hyperplastic changes in the alimentary tract of the lactating rat. J. Pathol. Bacteriol., 85, 1: 179-188.

10. Frank F., 1952: Adaptionsversuche bei Feldmäusen (M. arvalis Pall). Ztschr. Tierpsychol., 9: 415-423.

11. Frank F., 1957: Reproduction potential of Microtus arvalis - peak production among mammals. Z. Säugtierk., 21, 3/4: 176-181.

12. Fuller F. M. \& C a d e nhead A., 1968: The preservation of feces and urine to prevent losses of energy and nitrogen during metabolism experiments. [In: "Energy Metabolism《. Proc. of IV Symp. of EAAP. Jabłonna, Sept. 1967, Ed. K. L. Blaxter]. (in print).

13. Górecki A., 1965a: The bomb calorimeter in ecological research. Ekol. pol. B, 11, 2: 145-158. [In Polish with English summ.].

14. Górecki A., 1965b: Energy values of body in small mammals. Acta theriol., 10, 23: $333-352$.

15. Grodziński W., 1967: Daily metabolism rate and body size in common voles (Microtus arvalis Pa 11). Small Mamm. Newslet., 1, 3: 5-6.

12 - Acta theriol. 
16. Grodziński W. \& Górecki A., 1967: Daily energy budgets of small rodents. [In: „Secondary Productivity of Terrestrial Ecosystems", Ed. K. P etrus ewicz], 1: 295-314. Polish Sci. Publ. Warszawa-Kraków.

17. J a n ský L., 1959: Working oxygen consumption in two species of wild rodents (Microtus arvalis, Clethrionomys glareolus). Physiol. Bohemoslov., 8, 5: 472478.

18. K a c z marski F., 1966: Bioenergetics of pregnancy and lactation in the bank vole. Acta theriol., 11, 19: 409-417.

19. Musialek B., 1968: The embryo and placenta weights of inbred and $\mathrm{F}_{1}$ hybrid mice in normal and heterospermic litters. Acta Biol. cracov., 11: 4451.

20. Myrcha A., 1964: Variations in the lenght and weight of the alimentary tract of Clethrionomys glareolus (S c hre be r, 1780). Acta theriol., 9, 10: 139148.

21. Myrcha A., 1965: Lenght and weight of the alimentary tract of Apodemus flavicollis (M elchior, 1834). Acta theriol., 10, 16: 225-228.

22. Nels on M. M. \& Evans H. M., 1961: Dietary requirements for lactation in the rat and other laboratory animals. [In: "Milk: the mammary gland and its secretion.", Ed. S. K. Kon \& Cow i e A.]. 2: 137-191, Acad. Press. New York - London.

23. Nijkamp H. J., 1965: Some remarks about determination of the heat of combustion and the carbon content of urine. [In: "Energy metabolism", Ed. K. L. B la x ter]: 147-157. London.

24. Pelikán J., 1959: Rozmnožovani, populačni dynamika a přemnožovani hraboše polniho. [In: "Hraboš polni - Microtus arvalis«, Ed. J. Kratochvíl]: 130-167. Praha.

25. Petrusewicz K., 1967: Concepts in studies on the secondary productivity of terrestrial ecosystems. [In: "Secondary Productivity of Terrestrial Ecosystems", Ed. K. Petrus ewicz]. 1: 17-49. Polish Sci. Publ. WarszawaKraków.

26. Skuratowicz W., 1963: Gryzonie. Biologia i zwalczanie gatunków szkodliwych. PWRiL: 1-172. Warszawa.

27. Snel1 G. D., 1956: Reproduction. [In: "Biology of the laboratory mouse«, Ed. G. D. Snel1]: 53-88. Dover Publ. Inc. New York.

28. Spector W. S. [Ed.], 1956: Handbook of biological data (Tabl. 34 and 35). W. B. Saunders Comp., Philadelphia - London.

29. Trojan P. \& Wojciechowska B., 1967a: Resting metabolism rate during pregnancy and lactation in the European common vole, Microtus arvalis (P a 11.). Ekol. pol. A, 15, 44: 811-817.

30. Trojan P. \& Wojciechowska B., 1967b: Resting metabolism rate in European common vole, Microtus arvalis ( $\mathrm{P}$ a 11.) in different ambient temperatures. Ekol. pol. A, 15, 43: 803-810.

31. Trojan P. \& Wojciechowska B., 1968: The effect of huddling on the resting metabolism rate of the European common vole, Microtus arvalis (P a 11.). Bull. Acad. Pol. Sci. Cl. II., 16, 2: 107-109.

Received, September 28, 1968.

Department of Animal Genetics \& Organic Evolution,

Jagiellonian University,

Kraków 2, Krupnicza 50, Poland. 
Paweł MIGULA

\section{BIOENERGETYKA CIĄŻY I LAKTACJI U POLNIKA ZWYCZAJNEGO}

\section{Streszczenie}

U 17 samic polnika zwyczajnego, Microtus arvalis ( $\mathrm{P}$ a 11 a s, 1779) metodą racji pokarmowych określono wydatki energetyczne związane z ciążą i laktacją. Wydatki te porównano $\mathrm{z}$ kosztami utrzymania kontrolnych samic nierozradzających się.

Samice nierozradzające się przyswajały $87,7 \%$ z podawanej diety złożonej z. owsa, marchwi i mleka. Straty energetyczne z kałem wynosiły $8,95^{\circ} \%$, a z moczem $3,33 \%$. Podobny współczynnik asymilacji stwierdzono u samic ciężarnych $(86,6 \%)$. Koszty utrzymania samicy polnika o średnim ciężarze ciała $25,3 \mathrm{~g}$, która jest poza okresem rozrodu, określono $\mathrm{z}$ energii przemiennej (asymilacji pokarmu) na $0,453 \mathrm{kcal} / \mathrm{g} /$ dobę.

W okresie osiemnastodniowej ciąży ciężar ciała samicy wzrastal średnio od $23,2 \mathrm{~g}$ do $33,9 \mathrm{~g}$. W tym czasie przyswajała ona średnio 249,7 kcal czyli około $13,9 \mathrm{kcal} /$ dobę. Energię zasymilowaną dodatkowio na ciążę oceniono na $60,5 \mathrm{kcal}$, co przewyższa zapotrzebowanie samicy nierozradzającej się o $32 \%$. Energia ta była wykorzystana na wyprodukowanie miotu złożonego średnio z 4,25 młodych o łącznym ciężarze $7,42 \mathrm{~g}(6,98 \mathrm{kcal})$.

W okresie laktacji następuje gwaltowny wzrost zużycia pokarmu od 15,3 kcal w pierwszym dniu do $39,6 \mathrm{kcal}$ w dniu piętnastym (Fig. 1). W porównaniu z samicą nierozradzającą się, zapotrzebowanie pokarmowe jest przeciętnie wyższe - $133 \%$. W czasie 16 dni laktacji samica przyswajała dodatkowo 243,5 kcal na wykarmienie 4,0 młodych, z których każde po 16 dniach ważyło średnio $9,87 \mathrm{~g}$ co odpowiada $47 \mathrm{kcal}$ (Fig. 2). Samice z większymi miotami ( $4-5$ młodych) zużywaly na karmienie o około $30 \%$ energii więcej niż samice $z$ miotami mniejszymi $(1-3$ młodych).

Wydajność produkcji netto w rozrodzie polników jest bardzo wysoka, wynosi ona $13,9 \%$ dla okresu ciąży i $15,4 \%$ dla okresu laktacji. W ciągu całej ciąży i laktacji zapotrzebowanie energetyczne samicy wzrasta przeciętnie o $82,5 \%$. Przy konstruowaniu dobowych budżetów energetycznych polników i obliczaniu przepływu energii przez ich populacje powinno się uwzględniać poprawki na rozród. Rozliczyć je można na przeciętnego osobnika w populacji, lub też dodawać według oszacowanej ilości miotów w całej populacji. 